\title{
Adding the Public Places of Ranya District on the Google Map
}

\author{
Akam Aziz \\ Department of Computer Science \\ University of Raparin \\ Ranya, Kurdistan Region, Iraq
}

\begin{abstract}
Map Online is one of the important reasons for citizens and tourists to find public places while trying to visit a place. In this research, we have considered the problems and lack of indeterminacy of the public places of Ranya district on Google Map, which is the best map over the world and has plenty of addresses more than any other maps around the world. Compare to the other countries, in all of the cities of Kurdistan Region and Iraq, most of the public places have not been determined and recorded. We, in this research which has taken over two years, have determined and recorded all of the public places such as education areas (colleges, schools, institutes, etc.), parks, tourist places, hospitals, government places, mosques, oil stations, police stations, and some other private and known places of Ranya district with all of its districts and villages. At this moment, compare to other districts of Kurdistan and Iraq, Ranya is the only place which $\% 95$ of its places have been determined and recorded on Google Map. Users whenever they want, wherever they are, or whichever device they use which is connected to Internet, can write the place they want without any other outer programs. Then, the direction of their places will be determined or they can call the determined place. Also, they will get a lot of images of the place. At this moment, the project has had three million views that the users have gained benefit from it. Our prime purpose in this project is to provide complete facilitation for citizens, strangers, and tourists who visit the area. We want these people to get the place they want without any guide.
\end{abstract}

Keywords- Google Map, Missing Place, Ranya

\section{INTRODUCTION}

The creation of online maps has increasingly influenced the people around the world (Peterson, 2014). In this regard, the Google Map and the Google Earth were introduced in 2005 and 2011 respectively (Wilken \& Goggin, 2017). The authentic satellite Google maps increasingly became advantageous. Using the maps for free has been indeed an extremely easy way to get the geographical information. With an increase in the incredible specialty of Google Map, like searching for a place or adding private or public places, one's location can easily be shared with others through emails and other ways of communication (Spivey, 2019). Street View and Sky View in $3 \mathrm{D}$ or helicopter in the cities of advanced countries could also be seen clearly (Sickle, 2015). Such innovations have also made it easier to get the sky pictures in a high quality and use them without any cost. Also, the photographers can share and post their photos continually from any place which has been determined on the Google Map. Furthermore, different service organizations, companies, and employers can create their own address map(s) to facilitate and provide the right location for people at any time (Schlein, 2006). Nonetheless, engineers, experts, and researchers of GIS can obtain the distance of any place or area without going there in person (Dodsworth, 2018). Despite the importance of determination of distance of one place to another through land, waterway, and skyway, these facilities have undoubtedly proved to be an incredible service for the users.

\section{DESCRIPTION OF THE PROJECT (METHODOLOGY)}

This project is the first project in Kurdistan aiming to entitle all the public places of Ranya District including all the towns and villages. At this moment, Ranya District is the first district with all its public places being determined on the Google Map. If the user wants to search for any place (such as governmental places, schools, colleges, institutes, mosques, oil stations, parks, tourist places, bridges, industrial places, and archaeological places), he/she can find the determined place(s) through Google Map without any problem (Gralla, 2011). It also helps in determining the direction of the place as well as the distance from the current location to the destination even through SMS (Purdy, 2013). At the same time, there are phone number(s) and photos of the respective places making it easier for the individual to reach to the real-time location (Raphael, 2019).

\section{PROBLEM STATEMENT}

In Iraq and Kurdistan region, unlike the other countries, a lot of public and private places have not been determined on Google Map. Therefore, it is a problem and a conspicuous lack for a person or user who wants to determine a place on the map or get the direction of the place (Get Direction). This project for Ranya District was an absolute necessity to make search easier for all the users of online map.

\section{PROBLEM SOLUTION AND OBJECTIVES}

The Google Map has become an unquestionable necessity as the most used online map. The absence of the address of any public and private place makes it difficult for the people who want to find the determined place. Through our project, we are able to solve this problem in our area including its districts and villages. At this moment, Ranya has become a city like other advanced cities over the world as all its places have been determined on the map. The user can find the place(s) through Google Map. The purpose of the project in entitling Ranya district is to make it renowned around the world. All the Internet users can search for it using the English and Kurdish language options. 


\section{IMPLEMENTATION}

Entitling and determining the private and public places on the online maps takes a lot of time, effort, and prudence (Gubrium, 2016) considering the following steps beforehand to confirm the project:

- Gathering information about the place;

- Visiting the place to put onto the map accurately;

- Taking some pictures of the place and putting them onto the map.

Taking these steps require a practical plan to get the desired result. In order to determine any place, we visited the place in reality whether a governmental place in the center of the city or district, or a school in the remote village of the Ranya Directorate. Visiting the place is another reason for the success and accurate result of the project considering that Google Map revises and checks the recommended place before actually placing it on its application. All the people who are entitled and add public and private places to Google map are required to abide by the rules and instructions of Google Map considering the necessity of accurate information. The Local Guides offer a suggestion to add the places to Google Map by providing accurate information. In case of not giving accurate and suitable information, Google Map refuses to add it.

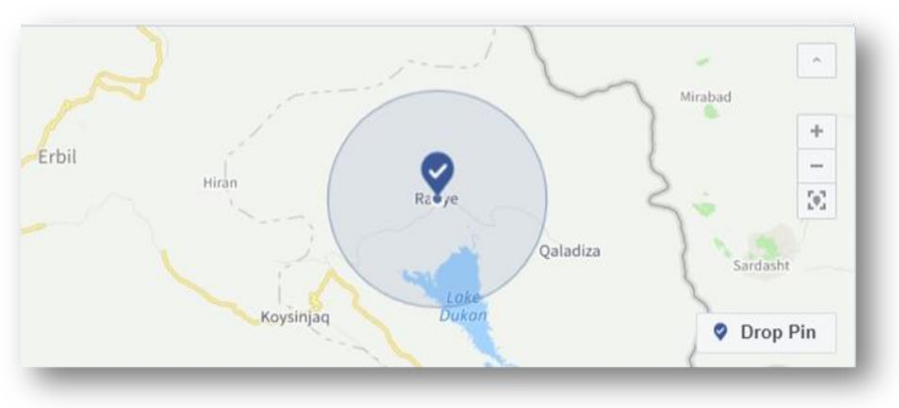

Figure 1: Ranya Zone

\section{RESULTS}

After working for two years in Ranya zone of the Kurdistan Region of Iraq, we successfully determined 746 public places in the district and took over 10000 pictures and recorded 80 videos for Google Map. For the determination of the direction of the place for anyone who wants to get to the wanted place from his or her own place, address of the place was written in the Google Search without using another program. This is an easier step for the users.

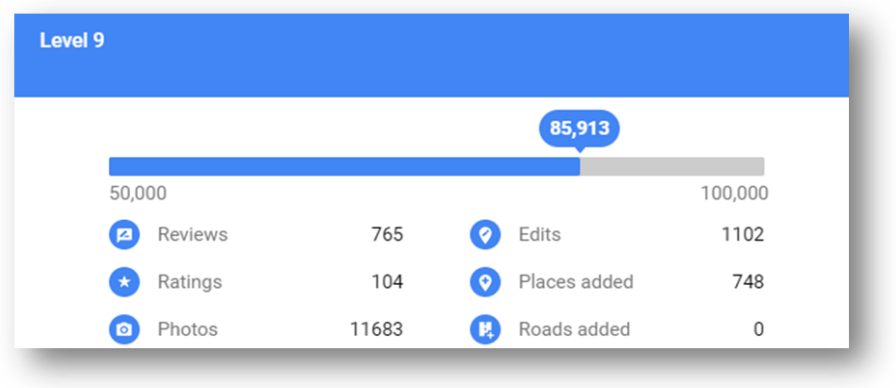

Figure 1: My Level on Google Map

\section{RECORDING THE PHONE NUMBERS OF THE PLACES}

Another step in our project that should be available for all the users now and in the future is providing the phone number(s) of the place like entitling the other countries. So, depending on the information of formal Statistics directorate of Raparin, we have added most of the phone numbers of public places. This makes the visit easier for the visitors.

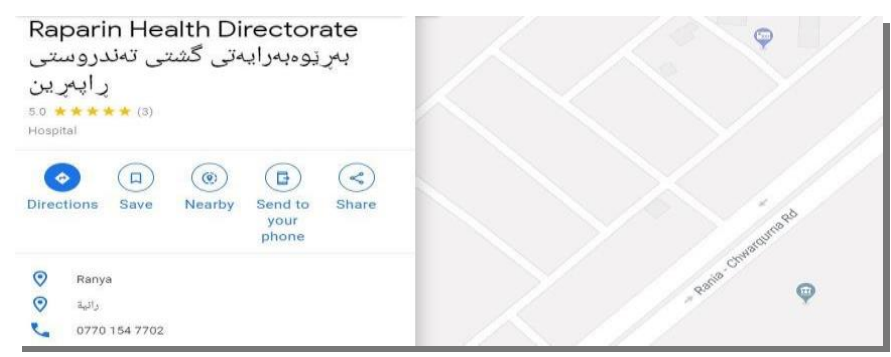

Figure 3: Adding Phone Number

\section{VIII.RECORDING THE PHOTOS OF THE PLACES}

Another great advantage for the visitors and Raparin district now and in the future is taking pictures of all the public places in a high, academic and new quality that will be an easy way for the person who is looking for the place or he or she wants to get information about the place beforehand. Because of that, we have taken and recorded a picture or more than a picture and published in the determined place.

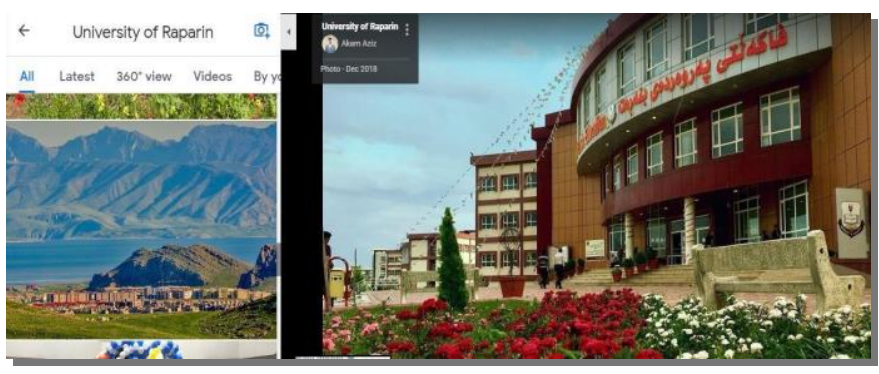

Figure 4: Adding Photo

\section{RECORDING ESSENTIAL INFORMATION}

Another advantage and usefulness of our project is mentioning and giving some information about most of the determined places. This is another facility for those people who want to more about the place too.

\section{SEARCH FOR LOCATIONS}

The user can use some different ways to search the determined place. In a way that she or he can write the name of the place in Kurdish directly. At the same time, the name of all the places can be found in a list too. For example, if we want to search for the governmental organizations of the center of Ranya, we can write Ranya Government Office in Google Search or Google Map. These are some types of searching to provide the place that we have added to our places: 


\section{Ranya city}

Ranya Government Office

Ranya Garden

Ranya Mosque

Ranya School

Ranya College

Ranya Institute

Ranya Hospital

Ranya Civil Police

Ranya Stadium

Ranya Petrol Statio

Ranya Town Halls.

Ranya Resorts

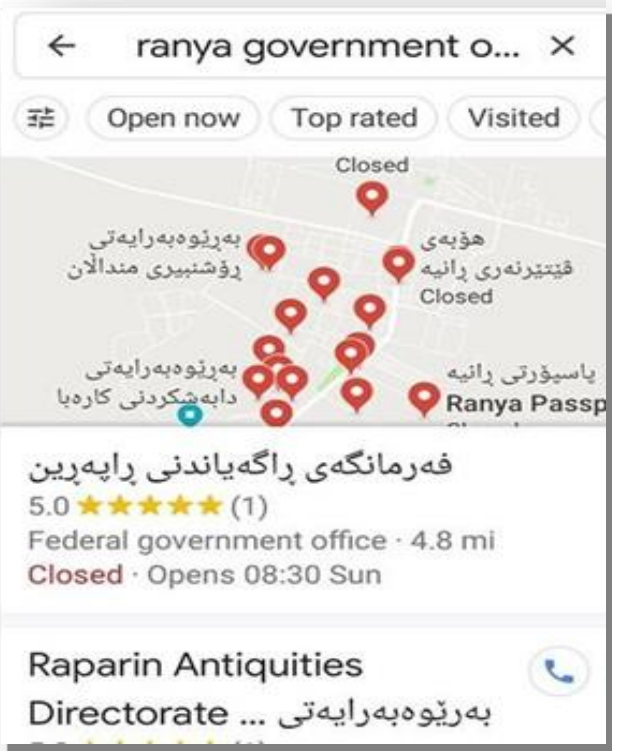

Figure 5: Search for Ranya Public Places

\section{B. Hajiawa Town}

1) Hjiawa Government Office

2) Hajiawa Garden

3) Hajiawa Mosque

4) Hajiawa School

5) Hajiawa Hospital

6) Hajiawa Civil Police

7) Hajiawa Stadium

8) Hajiawa Petrol Station

9) Hajiawa Town Halls

10) Hajiawa Resorts

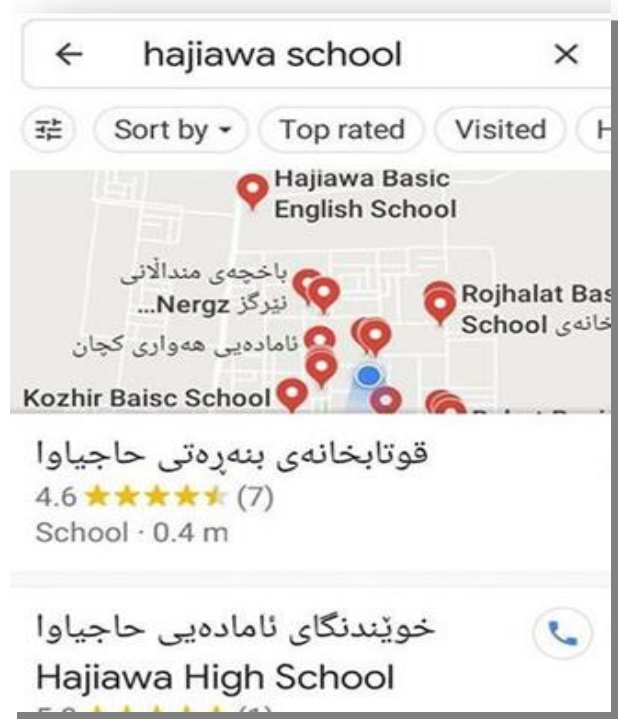

Figure 6: Search for Hajiawa Public Places

C. Chwarquran Town

1) Chwarquran Government Office

2) Chwarquran Garden

3) Chwarquran Mosque

4) Chwarquran School

5) Chwarquran Hospital

6) Chwarquran Civil Police

7) Chwarquran Stadium

8) Chwarquran Petrol Station

9) Chwarqurna City Town Halls

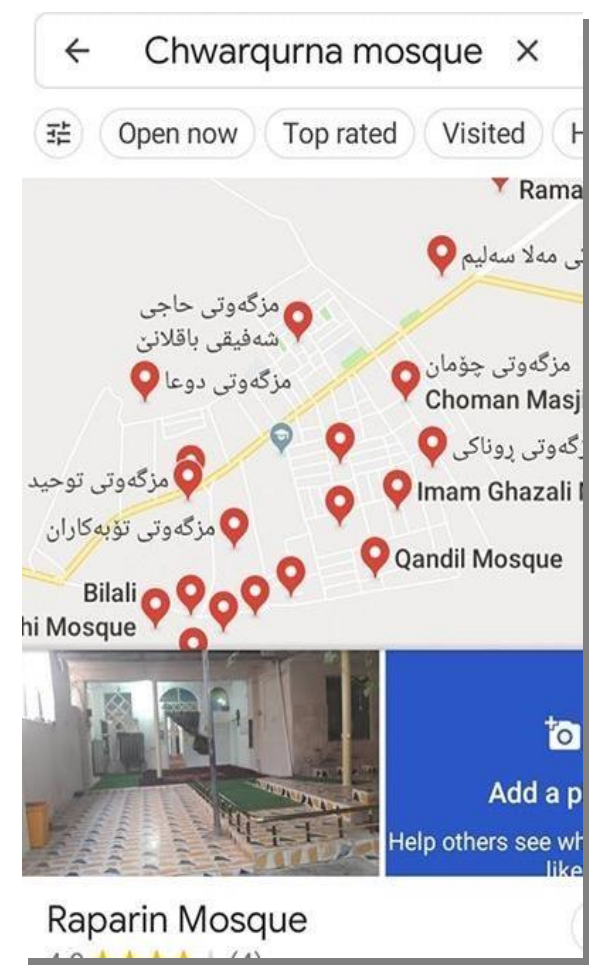

Figure 7: Search for Chwarqurna Public Places 
D. Sarkapkan Town

1) Sarkapkan Government Office

2) Sarkapkan Garden

3) Sarkapkan Mosque

4) Sarkapkan School

5) Sarkapkan Hospital

6) Sarkapkan Civil Police

7) Sarkapkan Stadium

8) Sarkapkan Petrol Station

9) Sarkapkan Town Halls

10) Sarkapkan Resorts

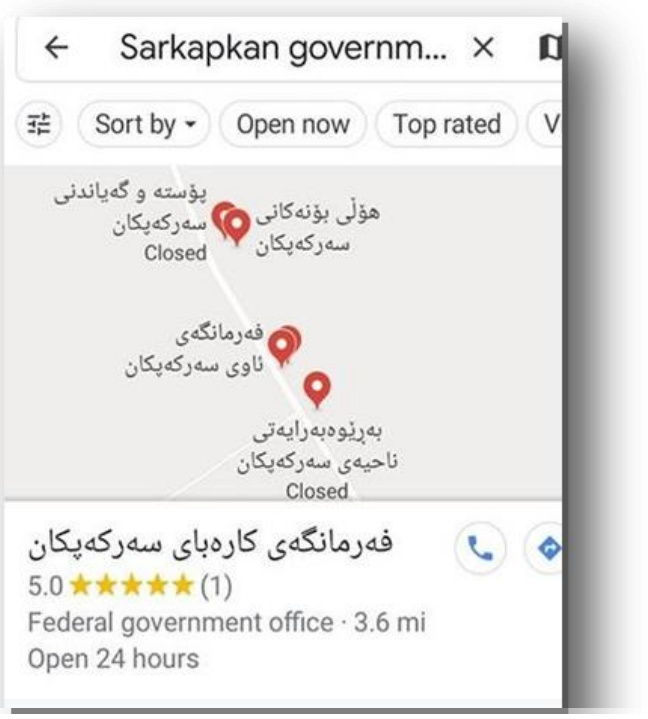

Figure 8: Search for Sarkapkan Public Places

E. Saruchawa Town

1) Saruchawa Government Office

2) Saruchawa Garden

3) Saruchawa Mosque

4) Saruchawa School

5) Saruchawa Hospital

6) Saruchawa Civil Police

7) Saruchawa Stadium

8) Saruchawa Petrol Station

9) Saruchawa Town Halls

10) Saruchawa Resorts

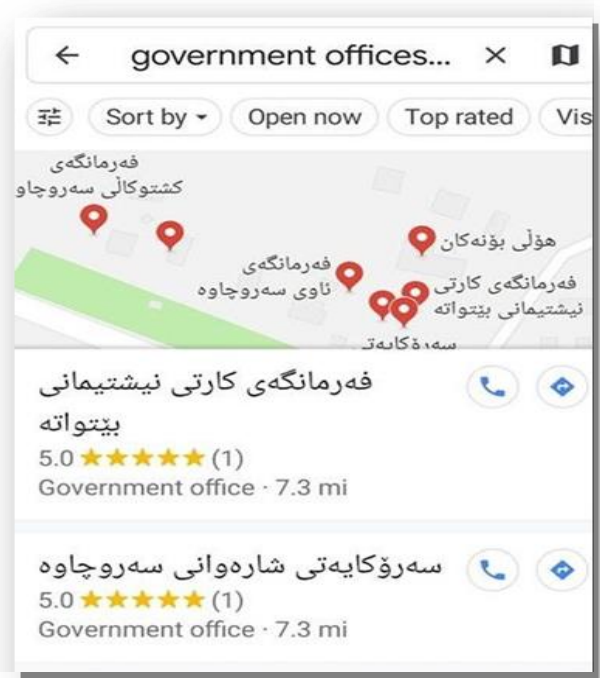

Figure 9: Search for Saruchawa Public Places

\section{MY PROFILE ON GOOGLE MAP AND POINTS, LEVELS, AND BADGING}

With adding and making any change in Google Map, Google gives points to the participants to encourage the volunteers. Earn points by contributing content to Google Maps. Score a place with ratings, describe your experience with reviews, share photographs and videos, provide insights with answers, respond to questions about a place, update information with place edits, add missing places, or verify information by checking facts (Google, 2019) .Getting points according to the type of the work is like that:

\begin{tabular}{ll} 
Maps contribution & Points earned \\
Review & 10 points per review \\
Review with more than 200 characters & 10 bonus points per review \\
Rating & 1 point per rating \\
Photo & 5 points per photo \\
Video & 7 points per video \\
Answer & 1 point per answer \\
Respond to Q\&As & 3 points per response \\
Edit & 5 points per edit \\
Place added & 15 points per place added \\
Road added & 15 points per road added \\
Fact checked & 1 point per fact checked \\
\hline
\end{tabular}

Figure 10: Points, Level, Badging

XII. LOCAL GUIDES LEVELS

Determining the levels of the people who are working to enrich Google Map is divided into ten levels, like this:

$\begin{array}{lll}\text { Level } & \text { Points } & \text { Badge } \\ \text { Level } 1 & 0 \text { points } & \text { No badge } \\ \text { Level } 2 & 15 \text { points } & \text { No badge } \\ \text { Level } 3 & 75 \text { points } & \text { No badge } \\ \text { Level } 4 & 250 \text { points } & \\ \text { Level } 5 & 500 \text { points } \\ \text { Level } 6 & 1,500 \text { points } \\ \text { Level } 7 & 5,000 \text { points } \\ \text { Level } 8 & 15,000 \text { points } \\ \text { Level } 9 & 50,000 \text { points } \\ \text { Level } 10 & 100,000 \text { points }\end{array}$

Figure 11: Local Guides Levels

After determining 746 public places in the district and recording over 10000 pictures of the places that has been added and 80 videos for Google Map. Also, we have put 762 notes about the places that has been added like revising and adding information to make it clear for the users. In spite of that, I have answered 1500 questions that Google has asked me after adding the places about the specialty of the place while offering services. So, my level is 9 in Google after gathering 85,500 points. This comes after working, searching, and going to all the places of Ranya City, towns, villages, streets, tourist places, mountains, and 
archaeological areas. Contributions must be based on real experiences and information. Deliberately fake content, copied or stolen photos, off-topic reviews, defamatory language, personal attacks, and unnecessary or incorrect content are all in violation of our policy. (Google, Local Guid , 2019).

\section{XIII.CONCLUSION}

We all can have similar thoughts about the importance of Google map, Google Map helps people to find places That caused a massive globalization process and affected people from all over the world, In our project, after specifying the entire public locations of Ranya District and fixing them on Google Map, we are planning to prolong the project and work on sulaymaniyah governorate to do the same as we did for Ranya city. We are working on making a general revision of what we did in order to fix the shortages that we may made.

\section{REFERENCES}

[1] Dodsworth, E. H. (2018). A research guide to cartographic resources: Print and electronic sources. Lanham: Rowman \& Littlefield.

[2] Gralla, P. (2011). Droid X: The Missing Manual. OReilly Media.
[3] Gubrium, A. (2016). Participatory visual and digital methods. London and New York: Routledge.

[4] Peterson, M. (2014). Mapping in the cloud. New York: Guilford Press.

[5] Purdy, K. (2013, June 24). Top 10 Things You Didn't Know Google Maps Could Do. Retrieved from https://lifehacker.com/top-10-thingsyou-didnt-know-google-maps-could-do-5525758

[6] Raphael, J. (2019, May 18). How to use Google Maps to help someone find you Retrieved from https://www.theverge.com/2019/5/18/18629379/how-to-googlemaps-location-sharing-meet

[7] Schlein, A. M. (2006). Find it online: The complete guide to online research. Tempe: Facts on Demand Press.

[8] Sickle, J. V. (2015). GPS for land surveyors. Boca Raton: CRC Press, Taylor \& Francis Group

[9] Spivey, D. (2019). IPAD FOR SENIORS FOR DUMMIES. JOHN WILEY \& Sons.

[10] Wilken, R., \& Goggin, G. (2017). Locative media. London: Routledge.

[11] Google. (2019). Local Guid. Retrieved from support.google.com:

[12] https://support.google.com/localguides/answer/6225851?hl=en\&auth user $=1 \#$

[13] Google. (2019). Local Guide. Retrieved from https://support.google.com/localguides/answer/7422880?hl=en\&auth user $=1 \&$ ref_topic $=6225845$.

\section{APPENDIX}

Some example of Ranya Public Locations

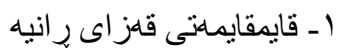

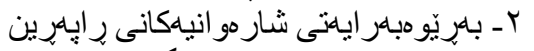

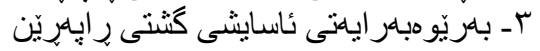

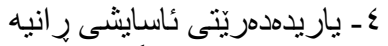

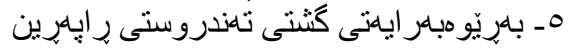

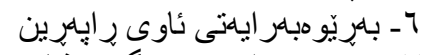

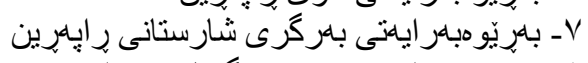

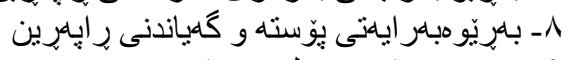

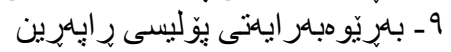

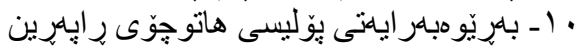

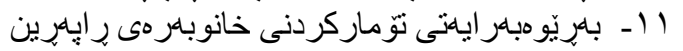

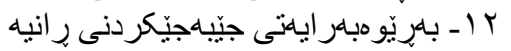

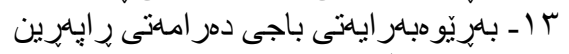

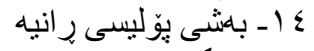

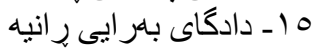

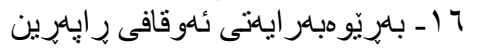

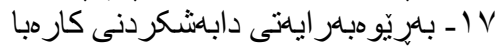

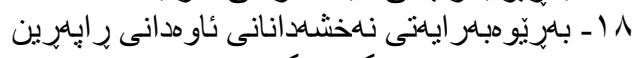

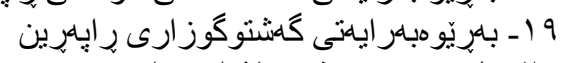

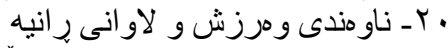

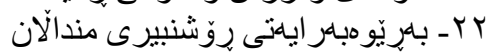

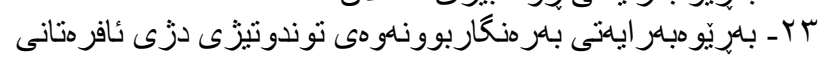

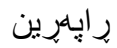

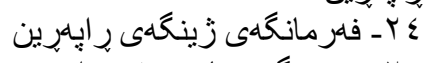

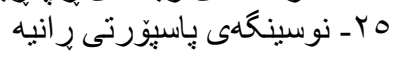

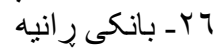

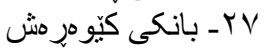

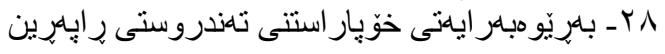

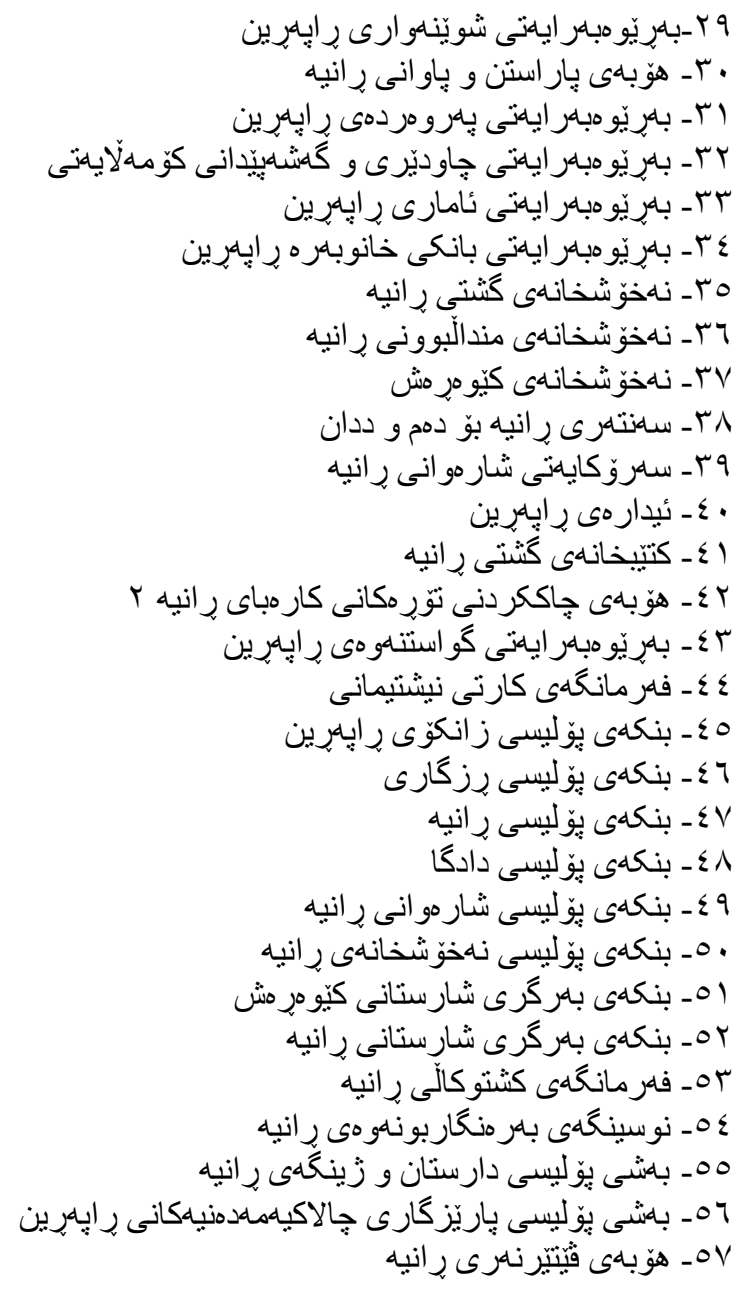

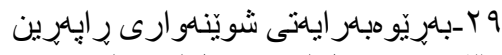

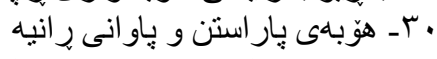

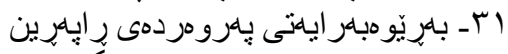

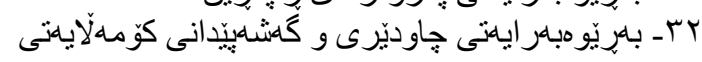

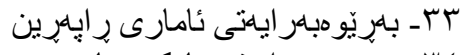

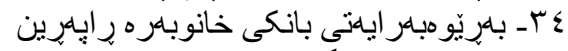

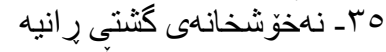

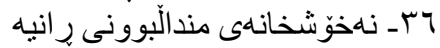

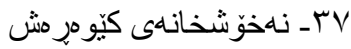

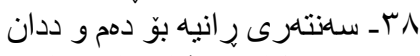

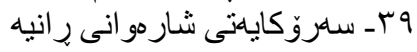

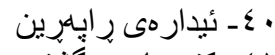

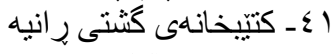

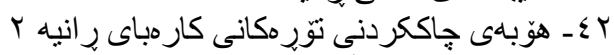

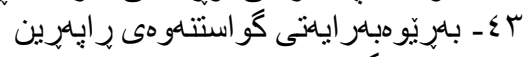

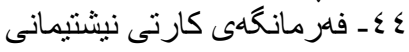

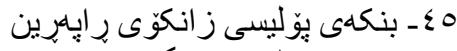

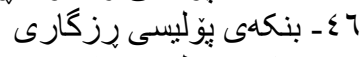

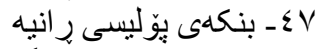

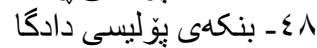

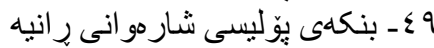

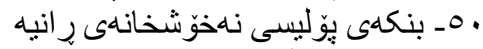

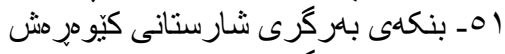
ror

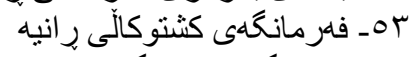

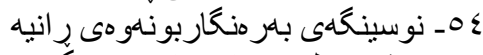

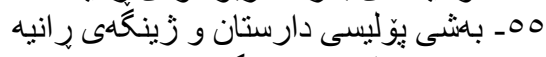

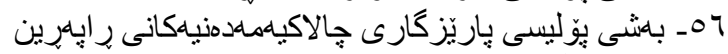

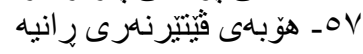




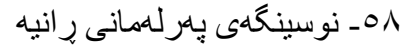

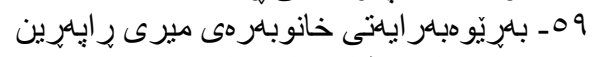

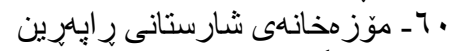

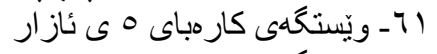

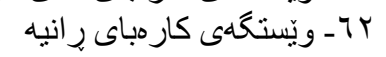

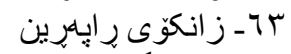

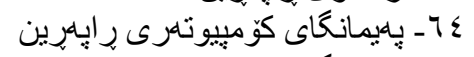

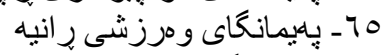

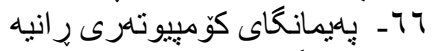

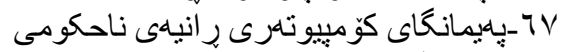

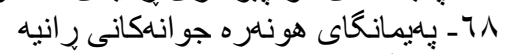

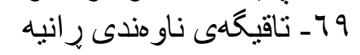

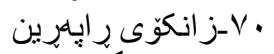

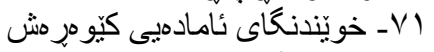

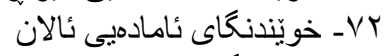

$$
\begin{aligned}
& \text { ك }
\end{aligned}
$$

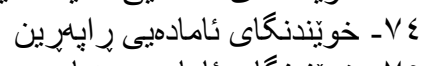

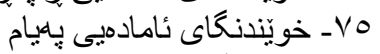

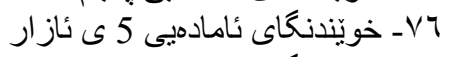

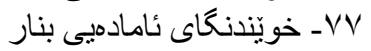

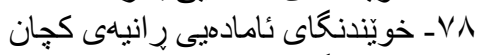

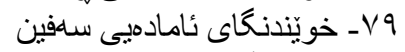

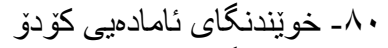

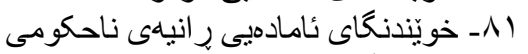

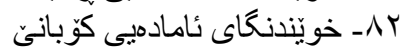

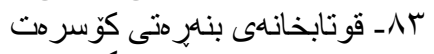

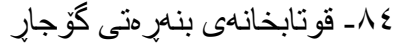

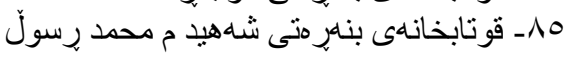

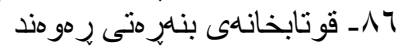

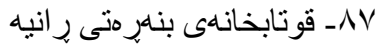

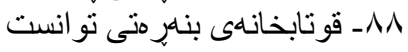

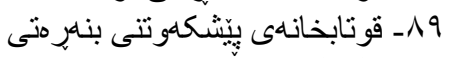

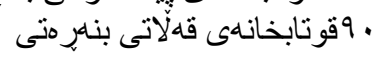

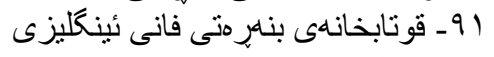

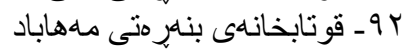

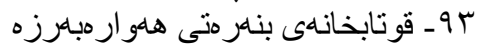

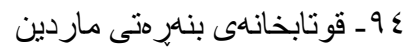

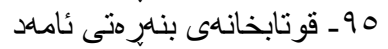

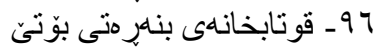

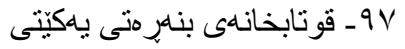

